IZA DP No. 10390

Economics of Civil Conflict:

Evidence from the Punjab Insurgency

Prakarsh Singh

November 2016 


\title{
Economics of Civil Conflict: Evidence from the Punjab Insurgency
}

\author{
Prakarsh Singh \\ Amherst College \\ and IZA
}

\section{Discussion Paper No. 10390 \\ November 2016}

\author{
IZA \\ P.O. Box 7240 \\ 53072 Bonn \\ Germany \\ Phone: +49-228-3894-0 \\ Fax: +49-228-3894-180 \\ E-mail: iza@iza.org
}

\begin{abstract}
Any opinions expressed here are those of the author(s) and not those of IZA. Research published in this series may include views on policy, but the institute itself takes no institutional policy positions. The IZA research network is committed to the IZA Guiding Principles of Research Integrity.

The Institute for the Study of Labor (IZA) in Bonn is a local and virtual international research center and a place of communication between science, politics and business. IZA is an independent nonprofit organization supported by Deutsche Post Foundation. The center is associated with the University of Bonn and offers a stimulating research environment through its international network, workshops and conferences, data service, project support, research visits and doctoral program. IZA engages in (i) original and internationally competitive research in all fields of labor economics, (ii) development of policy concepts, and (iii) dissemination of research results and concepts to the interested public.
\end{abstract}

IZA Discussion Papers often represent preliminary work and are circulated to encourage discussion. Citation of such a paper should account for its provisional character. A revised version may be available directly from the author. 
IZA Discussion Paper No. 10390

November 2016

\section{ABSTRACT}

\section{Economics of Civil Conflict: Evidence from the Punjab Insurgency}

The Punjab Insurgency in India (1978-1993) took the lives of over 20,000 people. Yet, there has been little research on the economic causes and consequences of the conflict in Punjab, which has been classified as a civil war and also an insurgency. In this article, I delve into some of the reasons for why Punjab suffered such a prolonged and bloody insurgency. Finally, I consider the macro and microeconomic effects of the conflict in Punjab that affected every walk of life and perhaps continue to do so today.

JEL Classification: D74

Keywords: Punjab, conflict, civil war, insurgency, India

Corresponding author:

Prakarsh Singh

Department of Economics

Amherst College

306B Converse Hall

Amherst, MA 01002-5000

USA

E-mail: psingh@amherst.edu

\footnotetext{
* Prepared for the Journal of Punjab Studies ed. by Prof. Nirvikar Singh and Prof. Jugdep Chima. I am grateful to Professor Nirvikar Singh for motivating me to write this essay and to Sam Alpert for excellent research assistance.
} 


\section{Introduction}

The Punjab Insurgency in India (1978-1993) took the lives of over 20,000 people (Singh, 2012; Telford, 2001). Yet, there has been little research on the economic causes and consequences of the conflict in Punjab, which has been classified as a civil war and also an insurgency. In this article, I delve into some of the reasons for why Punjab suffered such a prolonged and bloody insurgency. Finally, I consider the macro and microeconomic effects of the conflict in Punjab that affected every walk of life and perhaps continue to do so today.

Although there was a spike in violence related to civil wars in the 1990s after the collapse of the Soviet Union, the incidence of civil war as well as number of casualties in civil war have been on the decline ever since (Gleditsch et al. 2002). There has been a corresponding "substitution" of violence into localized insurgencies in South Asia and drug-related trafficking violence in Latin America. This pattern can also be seen in the Indian context, wherein civil conflicts morphed into localized insurgencies with multiple non-state actors in Kashmir, Assam and Punjab.

In this article, I outline (1) theoretical and empirical foundations of civil conflicts and insurgencies according to the broader economics and political science literature and then apply these to shed light on the case of the Punjab civil conflict (1978-1993), and (2) the macroeconomic and microeconomic consequences on Punjab's development following the insurgency.

\section{Empirical literature on the causes of conflict}

In order to understand the causes of civil wars, one needs to define civil wars and then code the data accordingly. There are several definitions of civil wars but the most popular has been that provided by International Peace Research Institute (PRIO)/Uppsala dataset: "A contested incompatibility which concerns government and/or territory where there is use of armed forces and at least 25 battle deaths per year." In this data set, 25-999 deaths per year is the criterion for a minor conflict and more than 1000 deaths per year is categorized as a civil war. Variables such as "type of war", start date, end date, battle deaths, and result are commonly included in data sets. There are obvious problems with this rather arbitrary definition, but as no better alternative is available, there seems to be an emerging consensus on using the above definition.

The Punjab civil conflict is classified as a civil war according to this definition between 1985 and 1993. A narrower classification may be an "insurgency". Fearon and Laitin (2003) define insurgency as "a technology of military conflict characterized by small, lightly armed bands practicing guerilla warfare from rural base areas." ${ }^{1}$

\footnotetext{
${ }^{1}$ Empirical economists do data-driven analyses ("run regressions") to understand a host of social, economic and political issues, and these techniques can also be applied to analyze the causes of war.
} 
probabilityofwar $=\alpha . G D P$ percapita $+\delta$.population $+\theta$.terrain $+\eta$.tradeopenness $+\varepsilon$

The variables on the right hand side of the above equation, also called explanatory variables, attempt to explain the variation in the left hand side variable. ${ }^{1}$ The coefficients next to an explanatory variable shows us the increase in probability of war if the corresponding variable is increased by 1 unit keeping all other variables same. The term $\varepsilon$ is a classical error term included to model any other factors that have not been included on the right hand side or those that cannot be measured but do influence the probability of war. The critical assumption is that $\varepsilon$ should not capture excluded explanatory variables; otherwise the estimates of coefficients will be different from their true value (i.e. biased). This assumption is very often violated as there may be omitted variables (such as education) that could be correlated with GDP per capita and also affect probability of war (due to opportunity costs of fighting). Therefore, a common strategy is to control for as many variables as possible on the right hand side. ${ }^{2}$ Another violation occurs due to reverse causality, where the left hand side variable (likelihood of war) affects any of the right hand side variables (income). For instance, people may stop investing in their businesses or there is selective migration in anticipation of conflict.

Despite these concerns, the earlier empirical literature in economics on civil conflicts points to the following correlations relying on cross-country regressions (regressions including values on all relevant variables from multiple countries):

(1) A lower per capita income and/or lower economic growth leads to a higher likelihood of conflict. This could be because of two reasons: a) The Collier and Hoeffler (1998) View: a reduced opportunity cost for engaging in violence (due to a decline in wages) and b) The Fearon and Laitin (2003) View: a reduced state capacity (which is proxied by a lower per capita income) for targeting anti-state actors.

(2) Mountainous terrain contributes to greater possibility of violence. This can be explained through a lack of economic development (which is difficult to achieve in mountainous terrain due to high costs of transportation) or because it acts as a refuge for rebel groups making the conflict persist (Fearon and Laitin 2003).

(3) Lower levels of schooling are correlated with violence. This is also consistent with the Collier and Hoeffler view laid out in (1).

(4) Most economists stress on the opportunity motive of a rebellion as laid out in (1)-(3) as opposed to the grievance motive. It is argued that because ethnic fragmentation, inequality, religious fractionalization and political participation are not significant in regressions, there is no grievance motive. This reasoning may be flawed for two reasons. First, we may not have adequate measures of inter-group inequality or the extent of religious polarization in society. Second, the regressions themselves suffer from serious econometric problems of reverse causation and omitted variables. 


\section{Conceptual framework}

Economists like to view actors as acting in their own self-interest even if the utility functions of these actors may be different. Modeling rebel groups as rational actors has gained currency in the theoretical economic literature. Several models predict the duration and the onset of civil war, how the rebel group would react to concessions and the effect of state's uncertainty about the strength of the rebel group on the outcome of the war (Collier, Hoeffler, \& Söderbom, 2004). The critical assumption is that both parties maximize their payoffs given their beliefs about the other party.

This rationalist approach, as exemplified in Jim Fearon's classic paper (1995), views conflict as an outcome when there is the impossibility of resolution through peaceful negotiations or concessionary bargains. He identifies three reasons why civil wars may take place:

(1) Asymmetric information - here, the relative strength of the two sides (typically, the government's army and a rebel group) is unknown to one another and there is no incentive to disclose to each other one's power. This causes one of the sides to overestimate its chances of winning the conflict and thus they are unable to settle for a negotiated bargain that would have been efficient. This is unlikely to have been a problem in Punjab, as the police and rebel groups appear to have been well aware of their relative military power (and progressively more so as the insurgency became prolonged).

Asymmetric information can often be caused by geography. In sociological research by Joyce Pettigrew (1995), a political leader told her:

"If only we had had the mountains or the sea, we would have had our freedom by now... the people are our jungle."

(2) Commitment problem - this issue is related to the dynamic nature of how conflict or peace affects one's strength in the future. If one of the sides (say, the rebel group) lays down arms in return for assurance from the government to give them amnesty or employment, there is an incentive for the government to renege on its promise after the rebel group has unarmed itself. On the other hand, there may also be preemptive strikes by the government against the rebel group (or vice versa) to not allow the balance of power to shift in the future. These theoretical reasons are not restricted to the explanation of civil wars. An example of a commitment problem is the American war on Iraq, which was based on the premise of possibility of nuclear weapons that would alter the relative future bargaining power between the US and Iraq.

(3) Issue indivisibility - it may also be impossible to bargain over conflictual issues that are indivisible (for example, the identity of the king, the state religion, or the state's capital). In this case, again, it is impossible to arrive at a peaceful negotiation.

\section{Application of theory to the context of Punjab}

In the rationalist strand of explanations for civil conflict, the theory of commitment problems seems to fit the scenario of Punjab. The insurgency began in 1978 as a religious movement. It advocated a separate country "Khalistan" with the insurgent group's disagreements with the center on economic issues. Despite 
a series of negotiations, there was no breakthrough between the Centre (represented by the then Prime Minister, Indira Gandhi) and the separatists (led by Jarnail Bhindranwale). Serious attempts at resolving the conflict took place in the aftermath of Indira Gandhi's assassination at the hands of her two Sikh bodyguards. In 1985, President's rule (a state of emergency) was lifted with the Rajiv Gandhi-Longowal Peace Accord, which referred all contentious issues to several commissions. But the accord was never fully implemented by the central government. In May 1987, due to political instability, President's rule was imposed again.

Two reasons may have contributed to this. First, there were commitment problems, i.e. no credible commitment mechanism for the separatists to believe in the Centre's offers. This would mean that once the extremists handed over their weapons, there would be an incentive for the government to renege on its promises. This commitment problem could have been potentially solved through a credible third-party commitment agency. The other option was to wage war.

Second, issue indivisibilities namely, river water sharing and Chandigarh being made capital of Punjab were issues that did not seem to have a bargaining equilibrium as there may have not been enough alternatives for the groups to choose from and the initial allocation of water rights was at stake. In this case, a search for a negotiated solution is usually futile (Richards and Singh, 2002). This problem was accentuated by the divisions among the militant groups themselves despite trying to forge alliances through committees.

\section{The (bread) basket case of Punjab ${ }^{3}$}

In many ways the insurgency story of Punjab is anomalous to the stylized facts of civil war literature on all three counts and there are no obvious economic causes for the insurgency. Punjab was one of the richest states in India at the start of the insurgency, did not experience serious economic recessions, has no mountainous area, and levels of schooling were not lower than several other peaceful states. ${ }^{4}$ Punjab ranked second in India in terms of HDI in 1981 (Indiastat).

Having a rural base in Punjab was essential to the insurgency as this helped provide cover from the state armed forces. Local knowledge allows the rebels to credibly threaten retribution for informing the police (Kalyvas, 1999). In Punjab, kidnapping was an efficient technology used by insurgents to extract their rents and the insurgency was informationally extremely localized, especially in villages (Singh, 2012).

The death toll in the Punjab insurgency rose from 1,333 in 1987 to 5,265 in 1991 and tapered to 871 in 1993. By 1994, the police declared that normalcy had returned. Along with an increase in police personnel, changes in foreign support due to sealing of borders with Pakistan and the curtailing of ISI funding by Benazir Bhutto contributed to usher in peace.

According to a village survey conducted by Puri et al. (1999), 65\% of the insurgents were from large families of landless laborers and marginal and small farmers while the majority of the remainder came from middle-class, rural families with over 5 acres in land holdings. $68 \%$ of the insurgents were between the ages of 18 and 25 and $70 \%$ of them were unmarried over the years of the insurgency (Singh and Shemyakina, 2016). Over the period of the conflict, $12.6 \%$ of persons killed by insurgents were women. In 
rural areas especially, it was not uncommon for young insurgents to sexually exploit women in households where they forcibly made their stay (Puri et al., 1999). In the last part of the paper, we explore the genderdifferential effects of the conflict in Punjab on education.

\section{Macroeconomic consequences of conflict on development in Punjab}

The 2004 Development Report states that Punjab's per capita income for 1979-1980 had grown to more than twice that of the all-India average.. However, by 1998-1999, Punjab's per capita income was only $44.30 \%$ higher than the all-India average (Government of Punjab, 2004). Punjab's growth per capita income was actually lower in the 1990's than the 1980's (2.72\% for the $1990 \mathrm{~s}$ vs. $3.42 \%$ for the $1980 \mathrm{~s}$ (Singh and Singh, 2002).

First, we assess the macroeconomic consequences of the conflict in Punjab. In order to understand the effect on Punjab's economic growth, we can study growth in Punjab versus India in five year intervals from 1960 until 2001-02. ${ }^{2}$ The growth rates are split by sector: Primary (P), Secondary (S) and Tertiary (T), before the Overall weighted average under " $O$ " in Table 1 . We observe two main patterns. First, the growth rates of Punjab and India appear to show a secular and consistent increase with the arrival of the green revolution in the late 1960s. However, beginning in 1974, India's overall annual compound growth rate is $5 \%$ and above, whereas Punjab records a higher than $6 \%$ growth before the onset of insurgency but slowly drops to under $5 \%$ per year in its aftermath. Second, there is growth in Punjab's manufacturing and services sectors (secondary and tertiary sectors) even in the 1990s but the substantial slowdown happens because of the decline in the agricultural sector (which contributed $48 \%$ to the state's GDP in 1981 and 1991). Punjab starts slowing down post 1990, especially in the primary sector. ${ }^{3}$

\footnotetext{
${ }^{2}$ Haryana may not be a pure control group because of negative spillover effects of violence to the neighboring state and also substitution of industries to nearby locations with lower levels of violence.

${ }^{3}$ A more sophisticated macroeconomic approach could resort to the methodology by Abadie and Gardeazabal (2003) who create synthetic controls for the Basque country that take other regions of Spain in a particular combination to generate the same pre-conflict growth trend.
} 
Table 1: Average Annual Compound Growth Rate of Gross State/National Income (\%)

\begin{tabular}{|c|c|c|c|c|c|c|c|c|}
\hline & \multicolumn{3}{|c|}{ Punjab } & \multicolumn{4}{c|}{ India } \\
\hline & P & S & T & O & P & S & T & O \\
\hline 1960-61 to 1965-66 & 2.4 & 6.0 & 4.5 & 3.6 & -0.9 & 6.9 & 5.6 & 2.7 \\
1965-66 to 1968-69 & 9.9 & 6.7 & 6.8 & 8.4 & 4.5 & 2.9 & 3.9 & 4.0 \\
$1970-71$ to 1975-76 & 2.86 & 5.87 & 5.95 & 4.21 & 0.5 & 3.9 & 4.5 & 2.5 \\
$1974-75$ to 1978-79 & 5.74 & 8.70 & 7.93 & 6.87 & 3.62 & 6.39 & 6.49 & 5.14 \\
$1980-81$ to 1984-85 & 5.37 & 5.04 & 5.14 & 5.23 & 5.63 & 6.05 & 5.42 & 5.66 \\
$1985-86$ to 1989-90 & 5.24 & 8.65 & 5.22 & 5.98 & 3.58 & 6.49 & 7.41 & 5.79 \\
$1992-93$ to 1996-97 & 3.08 & 7.10 & 5.78 & 4.81 & 3.85 & 8.28 & 7.87 & 6.76 \\
1997-98 to 2001-02 & 1.84 & 6.20 & 5.38 & 4.08 & 2.21 & 4.52 & 7.77 & 5.34 \\
\hline
\end{tabular}

Source: Statistical Abstracts of Punjab (Various Issues); Author's calculations

Note: (i) P - Primary sector, S - Secondary sector, T - Tertiary sector and O - Overall growth-rate.

(ii) Up to 1968-69 growth rates are at 1960-61 prices; for period between 1970-71 to 1978-79; at 1970-71 prices; between $1980-81$ and $1996-97$. at $1980-81$ prices, and for 1997-98 to 2001-02, at 1993-94 prices.

To dig deeper into the dismal performance of Punjab's primary sector, Figure 1 shows the trend of growth rate per annum for the Industry sector (blue) is relatively constant over the time period 19661999 with Livestock (purple) decreasing slightly throughout. Agriculture (green) has an initial spike from 1980-81 to 1990-91 with a sharp decline in 1991-92 to 1998-99 period visually showing the agricultural sector's collapse to a near $0 \%$ growth rate.

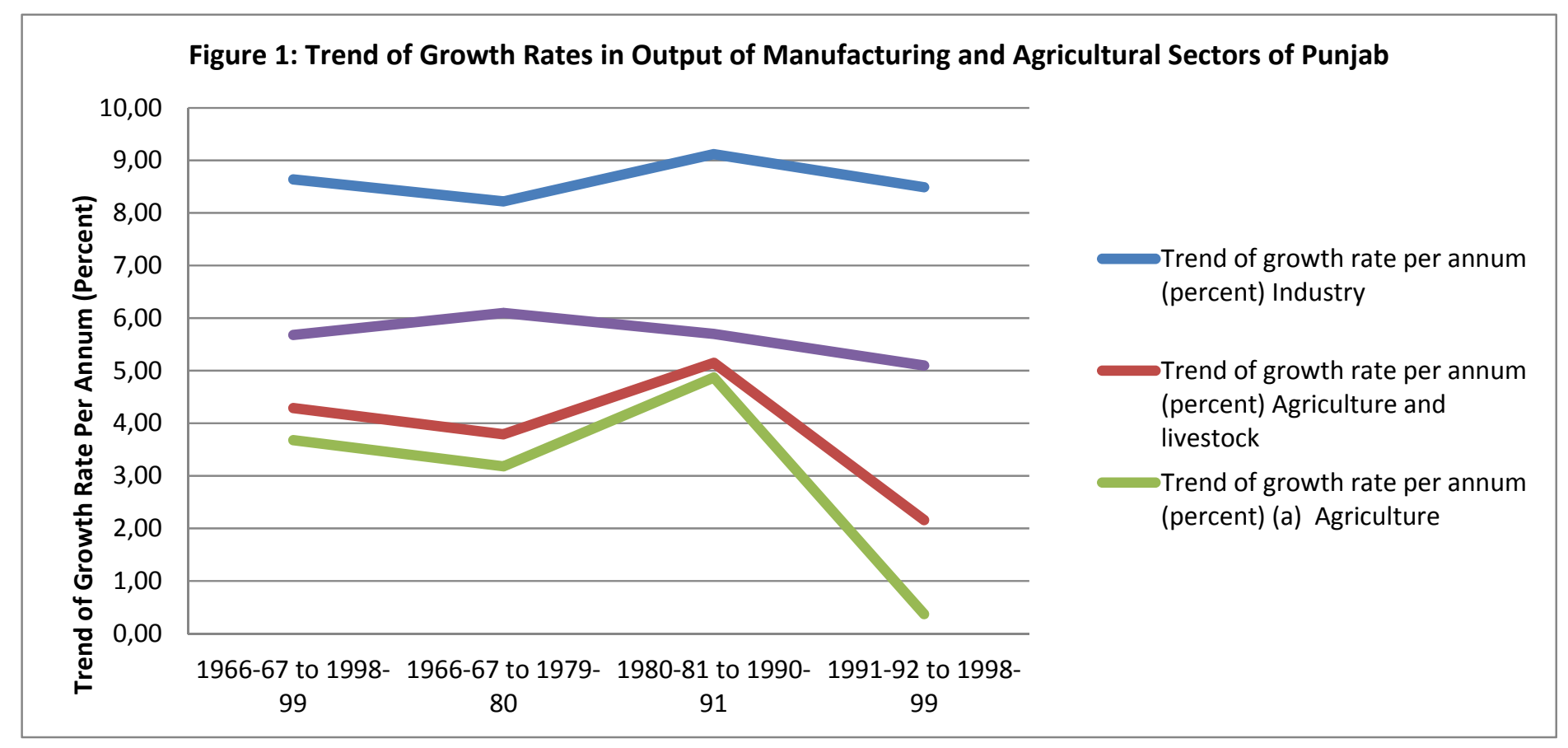

Source: Singh and Singh (2002); Author's calculations 
The agricultural growth slowdown in Punjab not only led to a loss in incomes but also reduced employment of agricultural laborers. Using data from the Census, Figure 2 shows that a majority of Punjab's workforce is engaged in Agriculture. However, from 1971 to 1991, the percentage of workers in Agriculture has decreased. The percentage of workers in the services sector ("others") has increased the most while manufacturing, construction, and transport, storage and communication appear to be relatively stable.

Employment in agriculture includes self-employed cultivators and agricultural laborers (hired labor). According to the 2004 Punjab Human Development Report, the percentage of cultivators in the workforce fell drastically from $43 \%$ to $31 \%$ between 1971-1991, whereas the proportion of agricultural laborers grew from $20 \%$ to $24 \%$. Manufacturing and services also grew modestly over the same period.

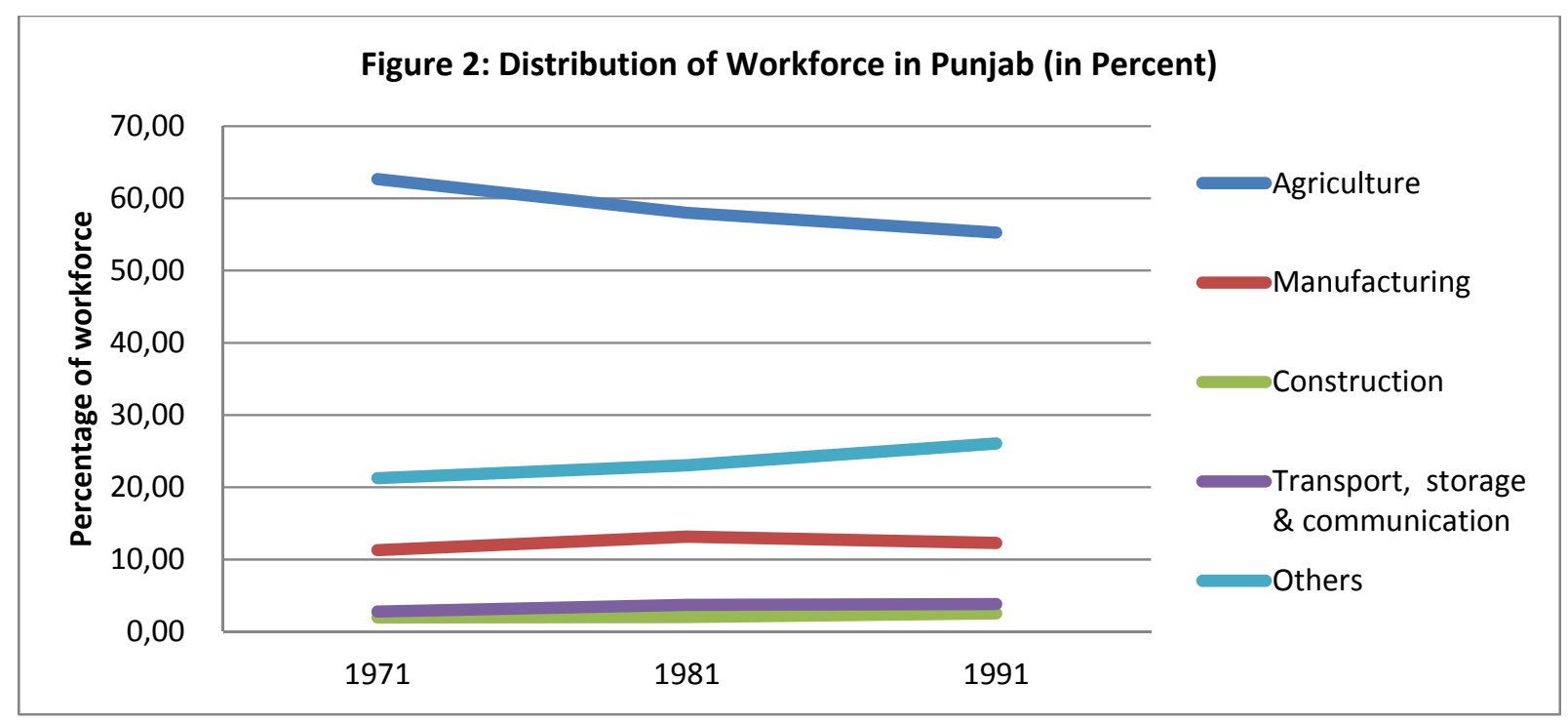

Source: Census of India 1971, 1981, 1991; Author's calculations

It is tempting to conclude that Punjab's slowdown in the 1990's was because of a secular decline in agricultural productivity. This could happen, for instance, if the returns to HYV seeds, fertilizers and irrigation diminished following the golden years of the green revolution. Even though the production process had become highly mechanized, and bullock cultivation had become replaced by tractor cultivation, the poor cultivators were often unable to buy capital that was needed. Aiyar (2012) argues that the notion that the insurgency caused Punjab's economic decline is a myth because the conflict ended two decades ago while Punjab's decline persists. Moreover, Indian states that face Maoist insurrections continue to record high growth. For example, Chhattisgarh has been greatly affected by conflict yet continues to be one of the fastest growing states in India (9.1\% average between 2002-03 and 2010-11) 
(Aiyar, 2012). On the other hand, a World Bank (2004) report conjectured that the agricultural decline happened due to a decline in long-term investment amid the uncertainty surrounding militancy.

Even though the macroeconomic data can provide us with clues as to the causal impact of the conflict, there could be other underlying factors (failure of governance, low technological growth) that may lead to both conflict and poor growth in incomes. Thus, macroeconomics research fails to shed light on the hypotheses posed above. To explain whether and how agriculture was affected by the conflict, we need to analyze microeconomic data.

\section{Transition to microeconomic research}

It is econometrically much cleaner to use individual-level or firm-level data sets as regressions using such data would not lead to the reverse causality bias. Hence, there has been a shift in the research frontier towards more micro-oriented research and towards understanding the consequences of conflict which is less prone to such biases. This shift towards micro-level analysis will continue as data gets sharper and more accessible and resources are channelized into conducting household surveys. However, the big picture is often lost in the process, as social gains become tougher to estimate and moreover, general equilibrium effects are not taken into account.

Microeconomic papers often employ a methodology that relies on the assumption that conflict affected areas would have had the same trend (in growth or investment) as peaceful areas if there was no conflict (also known as the common trends assumption). The advantage of this approach is that by only having data along two points in time, one can estimate a difference in growth for the treated group (here, conflict-prone districts) versus those in the control group (here, peaceful districts). There is an added bonus of restricting ourselves to the same institutional setup and not comparing apples (here, districts in Punjab) with oranges (districts in other parts of India). This approach is known as difference-in-differences.

By using individual-level data over time we can control for several omitted political and economic factors that are either fixed in a district over time or are changing over the entire state in a similar fashion every year.

\section{Punjab's conflict and agricultural labor spending}

In earlier work, Singh (2012) analysed farmer-level expenditure data from the Punjab Agricultural Department to study the effect of violence on labor spending. The farmer-level data on labor spending was collected and entered from annual surveys conducted by the Punjab Agricultural Surveys between 1978 and 1990. The main objective of the study of bullock-operated holdings was to assess expenditures of the cultivators in the state and to analyse the important changes which occur in farming. The study covers the entire state of Punjab in a repeated cross-sectional approach (where different farmers from the same sub-districts are sampled every year). One bullock-operated holding per sub-district has been surveyed. These holdings have been selected taking into account the cooperation, willingness and the capability of the cultivator in maintaining day-to-day records of his farm. ${ }^{5}$ 
There are two categories of manual labor spending: first, "Permanent manual labor spending" - which includes wages paid to labor hired for the entire year. If any family members were working on the farm, their forgone market wages were added to the permanent labor spending on the basis of wages paid to permanent hired labor in the village. The second category is Casual manual labor spending which includes wages paid to temporary labor hired during the year. Thus, effects on both permanent labor spending as well as casual labor spending can be estimated. On average, farmers spend close to $20 \%$ of their total farm expenditure on permanent labor and $7 \%$ of their farm expenditure on casual labor.

The data set on conflict has been obtained from the South Asia Terrorism Portal (SATP), which has a publicly-available district-wise record of all major conflict incidents in the state during the insurgency. The data on major killings begins in 1981. There are 1045 killings recorded in the data set and 149 incidents with at least 3 killings making one "major violence" incident. See Figure 3 for a timeline of the annual fatalities recorded in the Punjab insurgency. ${ }^{6}$

Figure 3: Annual Fatalities in Insurgency-Related Violence 1981-2013

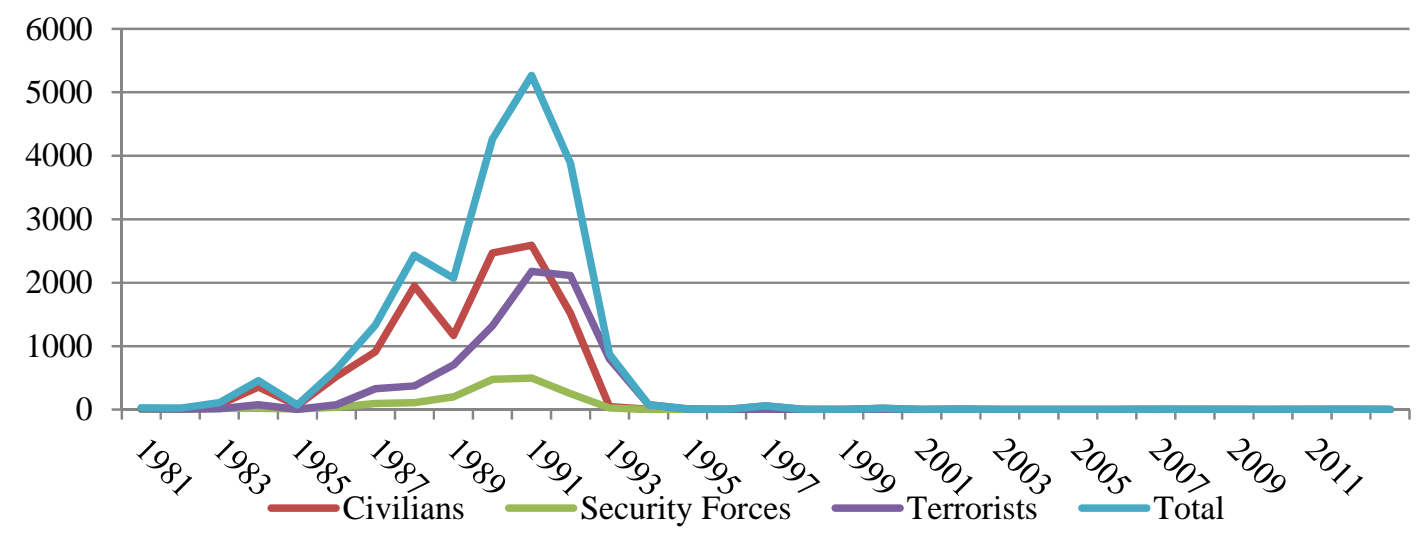

If the estimate of conflict on labor spending is negative, it can mean that labor might be more difficult to find as they may be looking to migrate or choose a safer profession within the village (supply-side channel as average wages did not decline during this period) or because of a complementary nature of labor with capital in the production function (demand-side channel).

Through the analysis of micro-level farmer expenditure surveys from the period 1981-1993, Singh (2012) finds evidence for an 11.4 percent decline in spending on permanent, but not casual, labor. This evidence suggests that insurgency-related violence adversely affected farmstead spending on permanent, but not temporary, hiring.

Decline in spending on 'permanent' labor can also be due to investment in technology such as tractors etc., which are more likely to be undertaken by richer farm households. If one assumes technology is not differentially distributed across districts and is not differentially changing across districts, the only differential factor would be violence and conflict. 
Moreover, Singh hypothesizes that these effects may not be a reflection of labor demand factors but rather labor supply shifts away from longer-duration contracts. Singh notes, however, that this effect appears to hold true only for the richer half of the surveyed farm households. This is consistent with the evidence on the decrease in employment in the agricultural sector but sheds light on the different mix of contracts that existed following the onset of the insurgency.

To analyze how the insurgency impacted Punjab's economy, it is critical to understand how violence affected investment decisions of farmers as these were the primary sources of state's GDP and engaged a large fraction of the workforce. A likely mechanism through which conflict affects investment is through firms facing the threat of extortion of their employees (human capital losses) or loss of property (physical capital losses). Regression analysis in Singh (2012) shows that violence leading to an increase in the probability of kidnapping (proxying for threat of extortion) turns out to be a significant channel.

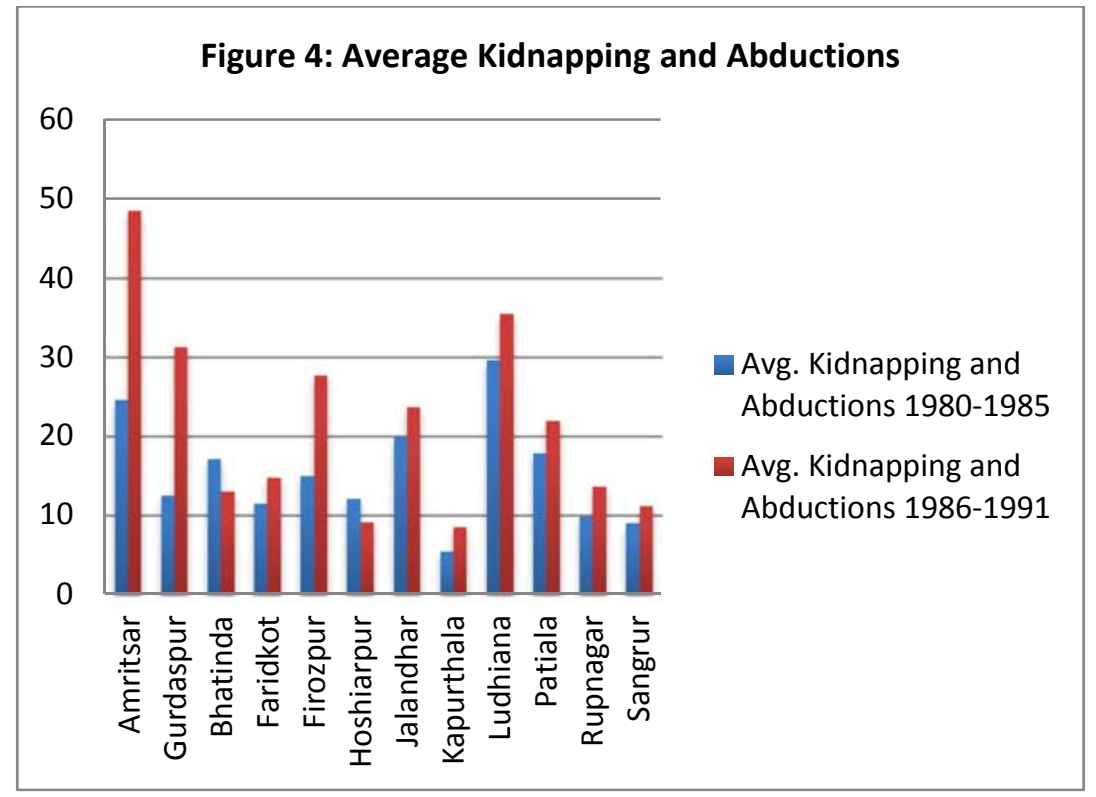

Figure 4 uses data from the New Delhi Crime Bureau's district reports and illustrates the increase in average kidnapping and abduction cases across all districts in Punjab, but especially in Western Punjab in Amritsar and Gurdaspur, where they doubled and also where the insurgency-related violence was the greatest. Puri et al. (2007) report several instances of kidnappings and extortions of rich farmers and businessmen that could have reduced long-term investments across sectors in Punjab. However, as Punjab is primarily an agricultural state, the greatest debilitating effects were seen in the agricultural sector.

Singh also finds that the district-level correlation between the presence of insurgent violence and kidnappings (and abductions) is close to five times higher in the following year as compared to the present year. These findings suggest that insurgent violence has the potential to signal an increase in future insecurity and may serve as a significant channel by which the effects on labor-related choices may work. 


\section{Punjab's conflict and agricultural investment}

Using data from annual surveys on representative farmers and district-wise major violent incidents from 1978-1989, Singh's (2013) paper published in the Journal of Conflict Resolution finds significantly large negative effects of conflict on the level of investment in long-term agricultural technology, proxied by farmer expenditure on wells. The presence of a major conflict incident in a given district in a year is associated with a reduction in long-term fixed investment by around $17 \%$ after controlling for district fixed-effects, time trends, district trends, and other farm-level controls.

In addition, these negative effects appear to be greater for richer farmers and those living in Pakistanbordering districts. Singh calculates that this reduction in long-term agricultural technology on account of the insurgency results in a farmer losing close to $4 \%$ of his annual income. Farmers' level of investment in short-term agricultural technology, proxied by farmer expenditure on fertilizer, is not found to be significantly affected by conflict.

\section{Punjab's conflict and human capital development}

Singh and Shemyakina (2016) use the 2005 India Human Development Survey (IHDS) to explore the longterm effects of the Punjab insurgency on educational attainment of adults who were between the ages of 6 and 16 at the time of the insurgency. They find a substantial and statistically significant negative effect of conflict on female educational attainment. This loss amounts to a 0.83-0.91 years of school for a one standard deviation increase in conflict activity measures. This decline in female educational attainment is further accentuated by the fact that women in Punjab have on average only 4.83 years of education.

Singh and Shemyakina also find evidence that suggests that in the presence of conflict and its associated constraints on resources, parents may prefer investing in the education of sons at the expense of their daughter's educational attainment. Therefore, a reduction in household expenditure on education appears to be one of the channels through which a shock imposed by the conflict hindered human capital accumulation by women. These findings have major implications about increased gender inequality during conflict and post-conflict periods, which are likely to harm long-term and even inter-generational human development for women.

The negative effects of conflict may reverse with regard to female employment rates. . For instance, Shemyakina (2011) finds that young women residing in conflict regions in Tajikistan are more likely to be employed in the last 14 days compared to women in non-conflict regions. Similarly, Menon and Rodgers (2011) find that as result of the Maoist-led insurgency, women's employment probabilities were substantially higher in 2001 and 2006 relative to the outbreak of war in 1996.

\section{Implications for future research}

The research frontier has expanded by leaps and bounds in recent years. However, there are still important questions that have not been answered convincingly. Not only would the answers be of 
academic value, but of use to policymakers as well. Future research on the impact of conflict in Punjab can analyze the following issues:

a) Effects of Punjab's conflict on the manufacturing sector. Even though it is likely that manufacturing firms suffered as a result of the insurgency due to poor governance, uncertainty, loss of capital and infrastructural damage, it is by no means obvious that the effect of conflict on firms is always negative, especially during is a resource-based conflict. Indeed, the impact of civil conflict on individual firms has been studied with a unique methodology by Ferrara and Guidolin (2004). They look at diamond mining firms in Angola and find that a peace treaty between the rebel group and the group in power being perceived as "bad news" by the market. Using stock market data on these firms and also forming a set of control firms which did not have concessions in Angola, they notice abnormal returns falling by 4 per cent on the day the Cease-fire agreement is signed ${ }^{7}$. They conclude that some firms may gain from the continuation of conflict because of the decreased transparency of licensing, barriers to new entrants and lower government bargaining power during conflict.

There can also be research on finding the duration of first-order effects. This will require detailed data with a longer window. How long does investment in the primary, secondary and tertiary sectors suffer for after the insurgency ends or are there immediate peace dividends? There has also been little research distinguishing outcomes during and post-conflict.

b) Effects of Punjab's conflict on consumption. An important determinant of GDP apart from investment is the consumption of individuals. Among what groups of individuals does consumption pattern change post-conflict? Becker and Rubinstein (2004) show using micro level data from coffee shops in Israel that consumption substantially decreased after terror strikes, but this was not the case for consumers who were spending a large amount of their income on such consumption. They also show similar patterns for bus rides.

c) Spillover effects of Punjab's conflict. Contagion of conflict to other states such as Haryana and Delhi may have led to negative spillovers on growth in neighboring states. However, there may have also been migration of productive individuals (and reallocation of investment) from Punjab to neighboring states spurring economic growth. It can be hypothesized that industries where investments that were more mobile may not have suffered as much as industries where investments are sunk. Conflict could have also incentivized accumulation of human capital in Punjab among certain groups (as it is a mobile form of investment). Another source of spillovers is the wave of international migration that took place in the 1980s to UK, Canada and the US. For instance, Murdoch and Sandler (2004) find that civil wars have an impact on not just the home country, but neighboring countries.

d) Finding new methodologies to control for learning. One possible study could be to find out which sectors of Punjab's economy were more prone to attacks and why. For example, if extremists blow up an oil pipeline (as is the case in Colombia) the stocks of multinational oil companies that have markets in Colombia could be compared with the stocks of the same company in a neighboring country. This strategy would help control for other shocks to the oil industry in that region that happen at the same time as the 
attacks. However, when major incidents become commonplace, markets would take into account the possibility of such attacks in the future and thus display no surprise when they actually take place. Distinguishing the learning effect from other simultaneous effects is a ripe area for research. Chen and Siems (2004) interestingly unearth the apparent resilience and fast recovery of the US stock markets compared to other markets after September 11, 2001. They conjecture that it is due to the stable financial sector that reaps liquidity and market stability. However, the exact reason was not recovered.

e) Better data collection. Individual-level surveys and firm-level data can help us shed light on the microeconomic consequences of conflict. These can be identified much more in a causal way as compared to the macroeconomic effects. Better surveys can be designed if they look at group inequality and also make use of psychological tests (self-control, grit, altruism) to control for previously unobservable variables. One important consequence for governments is to incentivize collection of data to understand the extent of inequality and polarization in society (Esteban and Ray, 1994). This will help us settle the debate on how polarization affected conflict in the case of Punjab.

\section{Conclusion}

Punjab's insurgency can be considered an anomaly because it does not conform to the usual correlates of conflict - as it is not a poor, mountainous and underdeveloped region and did not suffer from a recession prior to the onset of violence. However, within the rationalist strand of literature, commitment problems and issue indivisibilities were proximate causes for the rise of the insurgency. More work needs to be done to understand how the technology of conflict (kidnappings and extortion) funded the armed groups and the industrial organization of the multiple groups (including the state) engaged in violence.

Microeconomic studies show adverse effects of conflict on physical ${ }^{8}$ and human capital ${ }^{9}$. Moreover, these effects are disproportionately borne by poor, children and women (Shemyakina, 2006). Overall, there is undeniable evidence that Punjab's insurgency affected investment and growth in the agricultural sector. Whereas the smaller cultivators may have been hindered by a decline in productivity, the richer farmers appear to be affected more by the insurgency. They tend to reduce their long-term investment - such as investment in tube wells - but do not change their short-term investment decisions - for example, spending on fertilizers. This may lead to longer term and persistent effects that are still being felt in Punjab today. These negative effects were concentrated in the Pakistan-bordering districts. There are also larger negative developmental effects on labor spending and education. There was less spending on permanent labor and longer-term contracts in agriculture. The insurgency not only affected agricultural growth and the economic lives of those engaged in agriculture but also had wide-ranging impacts on human capital development. The conflict led to distortions within households also on spending on education. Due to a prevailing gender bias, conflict exacerbated the educational gap between girls and boys. This gender gap in education still persists today. 


\section{Work Cited}

Abadie, A., Gardeazabal, J., 2003. The Economic Costs of Conflict: A Case Study of the Basque Country. American Economic Review 93, 113-132. doi:10.1257/000282803321455188

Aiyar, S.A., 2012. Why Punjab Has Suffered Long, Steady Decline. Cato Institute. URL http://www.cato.org/publications/commentary/why-punjab-has-suffered-long-steady-decline (accessed 5.26.16).

Becker, G.S., Rubinstein, Y., 2004. Fear and the response to terrorism: an economic analysis. University of Chicago mimeo.

Bruck, T., 1996, “The Economic Effects of War,” mimeo, Oxford University, Oxford

Bueno de Mesquita, B., Smith, A., Siverson, R.M., Morrow, J.D., 2004. The Logic of Political Survival. The MIT Press, Cambridge, Mass.

Bundervoet, T., Verwimp, P., Akresh, R., 2009. Health and Civil War in Rural Burundi. J. Human Resources 44, 536563. doi:10.3368/jhr.44.2.536

Chen, A.H., Siems, T.F., 2004. The effects of terrorism on global capital markets. European Journal of Political Economy, 20, 349-366. doi:10.1016/j.ejpoleco.2003.12.005

Collier, P., Hoeffler, A., 1998. On economic causes of civil war. Oxf. Econ. Pap. 50, 563-573. doi:10.1093/oep/50.4.563

Collier, P., Hoeffler, A., Söderbom, M., 2004. On the Duration of Civil War. Journal of Peace Research 41, $253-273$. doi:10.1177/0022343304043769

Esteban, J.-M., Ray, D., 1994. On the Measurement of Polarization. Econometrica 62, 819-851. doi:10.2307/2951734

Fearon, J.D., 1995. Rationalist explanations for war. International Organization 49, 379.

Fearon, J.D., Laitin, D.D., 2003. Ethnicity, insurgency, and civil war. American political science review 97, 75-90.

Ferrara, E.L., Guidolin, M., 2004. Diamonds are Forever, Wars are Not: Is Conflict Bad for Private Firms? (SSRN Scholarly Paper No. ID 631608). Social Science Research Network, Rochester, NY.

Gleditsch, Nils Petter; Peter Wallensteen, Mikael Eriksson, Margareta Sollenberg \& Håvard Strand, 2002. ‘Armed Conflict 1946-2001: A New Dataset’, Journal of Peace Research 39(5): 615-637.

Government of Punjab, 2004. Punjab Human Development Report 2004.

IndiaStat.Com - India’s Comprehensive Statistical Analysis, Data Information \& Facts About India, URL http://www.indiastat.com/default.aspx (accessed 7.20.16).

Kalyvas, S.N., 1999. Wanton and senseless? The logic of massacres in Algeria. Rationality and Society 11, $243-285$. 
Menon, N., Rodgers, Y. van der M., 2011. War and Women’s Work: Evidence from the Conflict in Nepal (SSRN

Scholarly Paper No. ID 1976540). Social Science Research Network, Rochester, NY.

Murdoch, J.C., Sandler, T., 2004. Civil Wars and Economic Growth: Spatial Dispersion. American Journal of Political Science 48, 138-151. doi:10.1111/j.0092-5853.2004.00061.x

Osborne, M.J., 2003. An Introduction to Game Theory, 1 edition. ed. Oxford University Press, New York.

Pettigrew, J., 1995. The Sikhs of the Punjab: unheard voices of State and Guerilla violence. Zed Books.

Puri, H.K., Judge, P.S., Puri, H., 2007. Terrorism in Punjab: Understanding Grassroots Reality, 1 edition. ed. Har Anand Publications, New Delhi.

Resuming Punjab’s Prosperity. Poverty Reduction and Economic Management Sector Unit, South Asia Region, 2004. . World Bank, Washington, D.C.

Richards, A., Singh, N., 2002. Inter-state Water Disputes in India: Institutions and Policies. International Journal of Water Resources Development 18, 611-625. doi:10.1080/0790062022000017437

Shemyakina, O., 2006. The Effect of Armed Conflict on Accumulation of Schooling: Results from Tajikistan (HiCN Working Paper No. 12). Households in Conflict Network.

Singh, B.N., Inter State River Water Disputes in India: A Geographical Analysis.

Singh, G., 1996. Punjab since 1984: Disorder, Order, and Legitimacy. Asian Survey 36, 410-421. doi:10.2307/2645407

Singh, L., Singh, S., 2002. Deceleration of Economic Growth in Punjab: Evidence, Explanation, and a Way-Out. Economic and Political Weekly 37, 579-586.

Singh, P., 2012. Insurgency, crime, and agricultural labor expenditure: Evidence from Punjab, 1978-1990. The Economics of Peace and Security Journal 7. doi:10.15355/epsj.7.2.33

Singh, P., 2013. Impact of Terrorism on Investment Decisions of Farmers: Evidence from the Punjab Insurgency. Journal of Conflict Resolution 57, 143-168. doi:10.1177/0022002712464850

Singh, P., Shemyakina, O.N., 2016. Gender-differential effects of terrorism on education: The case of the 1981-1993 Punjab insurgency. Economics of Education Review. doi:10.1016/j.econedurev.2016.02.003

Telford, H., 2001. Counter-Insurgency in India: Observations from Punjab and Kashmir. Journal of Conflict Studies 21. 
${ }^{1}$ There is no perfect multicollinearity here between population and GDP per capita. To the extent that population is also included in calculated GDP per capita, the coefficients will still remain unbiased, but this is likely to increase the standard error, which in turn would lead to insignificance of the estimates. However, empirically, the coefficients are still significant.

${ }^{2}$ This approach is also called the water-sink approach - it may not be the most appropriate strategy if conflict influences the control variables, resulting in the reverse causality problem.

${ }^{3}$ The "Bread Basket” term is mentioned in the 2004 Development Report of Punjab (Government of Punjab, 2004) on page 17 with regard to Punjab’s lead in India’s Green Revolution of the 1960s.

${ }^{4}$ However, recent micro-level research on insurgencies supports the view that militancy is not correlated with poverty and lower education levels. This is consistent with the insurgency in Punjab, where those who took to arms on average were moderately educated and came from families owning small and medium sized farms.

${ }^{5}$ First, biases arising due to selection of villages within sub-districts, farmers within these villages and bullockholding farmers have been addressed in Singh (2012) where the bias (if any) would act in the direction of showing a lower effect than the true causal impact of conflict. Thus, our estimates for labour spending are also likely to be under-estimates. Second, as the annual data on conflict and extortions is compiled from January to December and that from agricultural surveys is recorded from July to June, there is a natural lag of six months between the ending of conflict and labour spending.

${ }^{6}$ Note that the insurgents are labelled as “terrorists” in the data set.

${ }^{7}$ The agreement came into place after Jonas Savimbi, the UNITA leader, was killed on February 22, 2002.

${ }^{8}$ One of the earliest papers in this sub-field is by Bruck, T., 1996, “The Economic Effects of War,” mimeo, Oxford University, Oxford. Bruck finds that Mozambicans lost $80 \%$ of their cattle stock during their civil war.

${ }^{9}$ A good paper with sound empirics is Akresh, R., T. Bundervoet and P. Verwimp. Forthcoming, "Health and Civil War in Burundi," Journal of Human Resources. They create instrumental variables from timing of armed clashes in the Burundi civil war to estimate impacts on child nutrition. Children who lived in a war-affected region have sharply lower height-for-age ratios. 